\title{
Genetic Variation of Spring Frost Damage in 3-year-old Fraser Fir Christmas Tree Plantations
}

\author{
Jennifer L. Emerson ${ }^{1,4}$, John Frampton ${ }^{2}$, and Steven E. McKeand ${ }^{3}$ \\ Department of Forestry and Environmental Resources, North Carolina \\ State University, Campus Box 8002, Raleigh, NC 27695
}

Additional index words. Abies fraseri, Abies, tree improvement, budbreak, bud flush

\begin{abstract}
A series of open-pollinated progeny tests of Fraser fir [Abies fraseri (Pursh) Poir.] was analyzed to determine genetic variation of spring frost damage to the terminal leader and lateral branches after a late season frost in May of the third year in the field. The level of spring frost damage was also compared with bud flush dates that had been measured in the nursery before field planting. Seed sources differed significantly for lateral branch frost damage, and families within source differed significantly for both terminal leader and lateral branch frost damage. Greater terminal and lateral frost damage were significantly associated with greater height for all years. As expected, parent elevation was negatively associated with progeny height. Less lateral frost damage was also associated with later terminal and lateral bud flush dates in the nursery. In addition, higher parent elevation was associated with later lateral bud flush dates of progeny in the nursery. Terminal and lateral bud flush dates in the nursery showed high individual tree within-population heritability values of 0.85 and 0.73 , respectively. Similar heritability values for the frost damage measurements were low, 0.045 for terminal leader damage and $\mathbf{0 . 1 4}$ for lateral branch damage. Many of the fast-growing families quickly made up for any loss of height from frost damage so that frost damage should not greatly affect the rotation length.
\end{abstract}

Fraser fir [Abies fraseri (Pursh) Poir.] is the only fir species native to the southern United States and is found naturally in a few stands at elevations of $1340 \mathrm{~m}$ to $2037 \mathrm{~m}$ $(4400 \mathrm{ft}$ to $6684 \mathrm{ft})$ in western North Carolina, eastern Tennessee, and southwestern Virginia (Dull et al., 1988). The climate in these natural stands is cool and moist with average daily temperatures ranging from -2 ${ }^{\circ} \mathrm{C}\left(28^{\circ} \mathrm{F}\right)$ during the winter to $15^{\circ} \mathrm{C}\left(59^{\circ} \mathrm{F}\right)$ during the summer (Beck, 1990). In addition to its importance in recreational areas of the southern Appalachians, Fraser fir also holds great economic importance as a Christmas tree species. It is considered a premier Christmas tree species and is grown in plantations

Received for publication 21 June 2006. Accepted for publication 1 Aug. 2006.

We thank the Christmas tree growers who maintained these progeny tests: Johnny Wishon, Wilson Barr, J. B. Greene, James Pitts, Dan McKinney, Thomas Beutell, Jerry Wilson, and Mark Cody. For the collection of the nursery budbreak data, we thank Glenn Howe. We acknowledge the North Carolina Division of Forest Resources, especially Joe Shoupe, for their work in culturing the seedlings in the nursery. We also thank AnneMargaret Braham, Jianfeng $\mathrm{Li}$, and the rest of the Christmas Tree Genetics program for their technical support. We also thank J. B. Jett and Fred Hain for their review of previous drafts of the paper.

${ }^{1}$ Graduate research assistant.

${ }^{2}$ Professor

${ }^{3}$ Professor and co-director of the NCSU Tree Improvement Cooperative.

${ }^{4}$ To whom reprint requests should be addressed; e-mail jlemerson@ncsu.edu. as Christmas trees throughout the southern Appalachians as well as other areas of the United States.

A test series consisting of open-pollinated progeny of parent trees from all six natural Fraser fir populations was planted in 2000 at eight sites in western North Carolina to determine the genetic variation among the six seed sources of Fraser fir and estimate genetic parameters for traits important in Christmas tree production. In 2002, the mountains of North Carolina experienced a severe late season frost in May with overnight low temperatures dropping below $0{ }^{\circ} \mathrm{C}$ for $5 \mathrm{~d}$ in some areas between 20 May and 24 May. Data from the Southeast Regional Climate Center shows the probability of having temperatures below $0{ }^{\circ} \mathrm{C}$ this late in May as ranging from less than $10 \%$ up to $30 \%$ at the climate stations in this region of the state, although the probability of having temperatures this low for multiple days in a row is likely much lower. This late frost brought temperatures below $0{ }^{\circ} \mathrm{C}$ and as low as $-4{ }^{\circ} \mathrm{C}$ to some areas, which caused severe damage to Fraser fir being grown as Christmas trees in the area, greatly impacting their height growth for that year and damaging lateral branches. This provided an excellent opportunity to study variation in spring frost resistance among these sources and families within sources. Although devastating late season frosts are uncommon, the losses from this frost were so great that it would be beneficial to determine if there were differences among sources and families within sources to frost damage.
Studies on coastal Douglas fir [Pseudotsuga menziesii var. menziesii (Mirb.) Franco] have found spring cold hardiness to be under strong genetic control (Aitken and Adams, 1997; Anekonda et al., 2000; O'Neill et al., 2000). The date of bud flush has also been shown to be under strong genetic control in coastal Douglas fir as well as Norway spruce [Picea abies (L.) Karst.], and later bud flush dates have been shown to be highly correlated with less spring frost injury in both species (Aitken and Adams, 1997; Hannerz et al., 1999b; Li and Adams, 1993; O'Neill et al., 2000). This correlation of bud flush dates with spring injury has also been shown in some Abies species (Jones and Cregg, 2006). A concern for tree improvement programs when selecting for frost resistance and later bud burst is the possibility of having a negative effect on height growth; studies in other tree species show differing results concerning correlations between bud burst and height growth. A study with Norway spruce has shown a positive correlation between late bud burst and greater height growth, indicating that later bud burst is associated with a longer duration of growth at the end of the growing season (Hannerz et al., 1999b). Contrary to this, a study on western hemlock [Tsuga heterophylla (Raf.) Sarg.] found that selecting families for increased height growth would be associated with earlier bud flush and a loss in spring frost hardiness (Hannerz et al., 1999a). The objective of the current study was to determine patterns of frost resistance in Fraser fir populations and how this is related to parent elevation, progeny height growth in the field, and progeny bud flush dates measured in the nursery before field planting.

\section{Materials and Methods}

Seedlings were grown from open-pollinated seed collected during a 1994 rangewide cone collection throughout Fraser fir's natural range (McKeand et al., 1995). Progeny from 188 of these trees were included in this study and were from the following six seed sources: Balsam Mountains, the Black Mountains, Grandfather Mountain, the Great Smoky Mountains, Mount Rogers, and Roan Mountain. The Great Smoky Mountains is the largest of the seed sources and is located along the border of North Carolina and Tennessee. Mount Mitchell, which is part of the Black Mountains, is the tallest mountain in eastern North America. The elevational ranges sampled from each source are shown in Table 1 and the locations of the six seed sources are indicated on the map in Figure 1.

Seeds were cold stratified from February until mid-April of 1997 and then sown into fine vermiculite in a greenhouse in Raleigh, N.C. Germinated seeds were transplanted into a 1:1 mixture of peat and perlite in Ray Leach Pine Cells (Stuewe and Sons, Inc., Corvallis, Ore) $\left(66 \mathrm{~cm}^{3}\right)$. The greenhouse design was four randomized blocks, each having as many as 51 germinants per seedlot. In March 1998, the seedlings were transported 
Table 1. The mean elevation and total elevational range of Fraser fir populations sampled compared with the population's actual maximum elevation as well as the number of families included in the progeny test from each population.

\begin{tabular}{lcccc}
\hline Source & $\begin{array}{c}\text { Number of } \\
\text { families }\end{array}$ & $\begin{array}{c}\text { Mean elevation } \\
\text { sampled }(\mathrm{m})\end{array}$ & $\begin{array}{c}\text { Elevational range } \\
\text { sampled }(\mathrm{m})\end{array}$ & $\begin{array}{c}\text { Population maximum } \\
\text { elevation }(\mathrm{m})\end{array}$ \\
\hline Balsam & 36 & 1722 & $1512-1871$ & 1954 \\
Black & 24 & 1723 & $1591-1859$ & 2037 \\
Grandfather & 32 & 1544 & $1457-1609$ & 1818 \\
Great Smoky & 46 & 1802 & $1487-1998$ & 2025 \\
Roan & 26 & 1709 & $1676-1743$ & 1916 \\
Rogers & 24 & 1597 & $1524-1658$ & 1746 \\
\hline
\end{tabular}

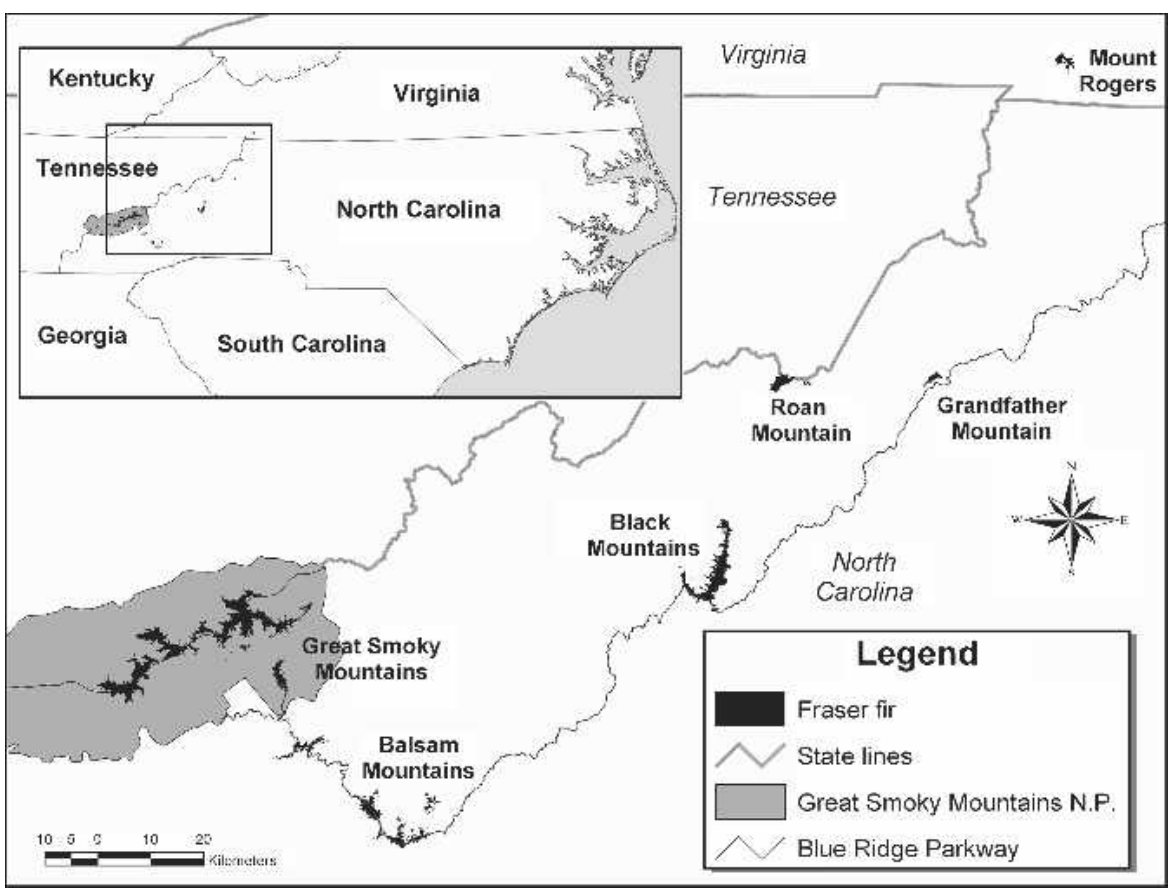

Fig. 1. Map of the natural range of Fraser fir (map by Kevin Potter). to the Linville River Nursery near Crossnore, N.C., where in June 1998, they were transplanted into fumigated nursery beds. The seedlings were planted in six-tree rows across the outdoor nursery bed at $15 \times$ $15 \mathrm{~cm}$ spacing. The greenhouse design of four randomized blocks with as many as 51 trees per plot was kept. The seedlings were operated by the North Carolina Division of Forest Resources using standard Fraser fir nursery practices, including irrigation, fertilization, weed control, and pesticide application. A subsample of trees was measured for date of terminal bud flush on the leader and bud flush on the lateral branches during the spring of 1999, their second growing season in the nursery. These data were collected by examining each tree in the four interior rows of the six total rows of each nursery bed. This was done seven times between the dates of 3 May and 25 May at 3- or 4-day intervals.

In the spring of 2000, seedlings were transplanted from the nursery beds to field trials. Progeny tests were established at eight locations in the mountains of western North Carolina testing a total of 188 open-pollinated families. Site characteristics for these tests are shown in Table 2. The families from each maintained in the Linville River Nursery seed source were divided equally into two groups with each group of families being tested at four of the eight sites. In each group, the number of families per seed source ranged from 12 to 26 . A randomized complete block design was used at each site with 35 replications and a single-tree plot per family. The seedlings were randomly assigned from the nursery bed blocks to the field tests. When enough seedlings per family were not available for all replications, another family was randomly substituted for it, and the replication in which the alternate family was used was randomly determined. The progeny test sites were located on working Christmas tree plantations and were each managed individually by the landowner according to their standard practices. This meant that each site was managed differently with respect to groundcover, pesticide applications, and fertilization. During the fourth year in the field, shearing began, which is a standard practice for Christmas tree production that involves cutting the terminal shoot and trimming the sides to increase density and enhance the conical Christmas tree shape (Chapman and Wray, 1989; Nichols, 1991). Shearing began during the fourth year in the field, before the year four measurements were taken. In this first year of shearing, only the tallest trees were sheared, with 4010 of the trees in the tests being sheared $(\approx 18 \%$ of the total). The sheared trees were included in the analysis because after comparing the height analysis with and without the sheared trees included, it was determined that the heritability value with the sheared trees included in the analysis was higher and most likely closer to what it would have been had they not been sheared (Emerson, 2004).

Height was measured each year in the field. In the spring of 2002, a severe frost occurred in late May. Figure 2 shows the actual minimum temperatures and the 30 -year average minimum temperatures occurring at weather stations in the two counties that had the highest amounts of frost damage, Ashe and Yancey. This climate data was obtained from the State Climate Office of North Carolina and the Southeast Regional Climate Center. The climate data for Ashe County was collected in Jefferson, N.C., at an elevation of $844 \mathrm{~m}(2770 \mathrm{ft})$, and the climate data for Yancey County was collected in Celo, N.C., at an elevation of $823 \mathrm{~m}(2700 \mathrm{ft})$.

Individual trees were rated in the field on the severity of the damage both to the terminal leader and to the lateral branches. The terminal leader was scored from 0 to 2 with 0 being no damage and 1 being some damage, in which the terminal was elongating when the frost hit but only a portion was killed. A score of 2 was given when the entire terminal was killed and a lateral branch became a new leader. The lateral branches were scored from 0 to 3 with 0 being no damage. A score of 1 was for light damage with $\approx 15 \%$ or fewer of the lateral branches
Table 2. Fraser fir progeny test site characteristics and the percent of trees with lateral frost damage at each site.

\begin{tabular}{|c|c|c|c|c|}
\hline Test location & Elevation $(\mathrm{m})$ & Aspect & Soil type & $\begin{array}{l}\text { Frost } \\
\text { damage }\end{array}$ \\
\hline Allegheny & 1055 & NW & Porters loam $10 \%$ to $25 \%$ slopes & $52.1 \%$ \\
\hline Ashe & 908 & $\mathrm{SE}$ & Watauga loam $8 \%$ to $15 \%$ slopes & $100 \%$ \\
\hline Avery & 1170 & Ridgetop & $\begin{array}{l}\text { Porters gravelly loam } \\
15 \% \text { to } 30 \% \text { slopes, stony }\end{array}$ & $43.8 \%$ \\
\hline Jackson & 1255 & NNW & $\begin{array}{l}\text { Cleveland-Chestnut-Rock outcrop } \\
\text { complex, windswept, } 30 \% \text { to } 50 \% \text { slopes }\end{array}$ & $63.0 \%$ \\
\hline Madison & 744 & NW & $\begin{array}{l}\text { Tusquitee-Whiteside complex, } \\
8 \% \text { to } 15 \% \text { slopes }\end{array}$ & $88.9 \%$ \\
\hline Mitchell & 1097 & SW & Saunook silt loam $2 \%$ to $8 \%$ slopes & $62.1 \%$ \\
\hline Watauga & 1219 & SSW & Porters loam, $15 \%$ to $30 \%$ slopes, stony & $32.7 \%$ \\
\hline Yancey & 957 & Level & Chandler-Micaville complex, stony & $96.6 \%$ \\
\hline
\end{tabular}



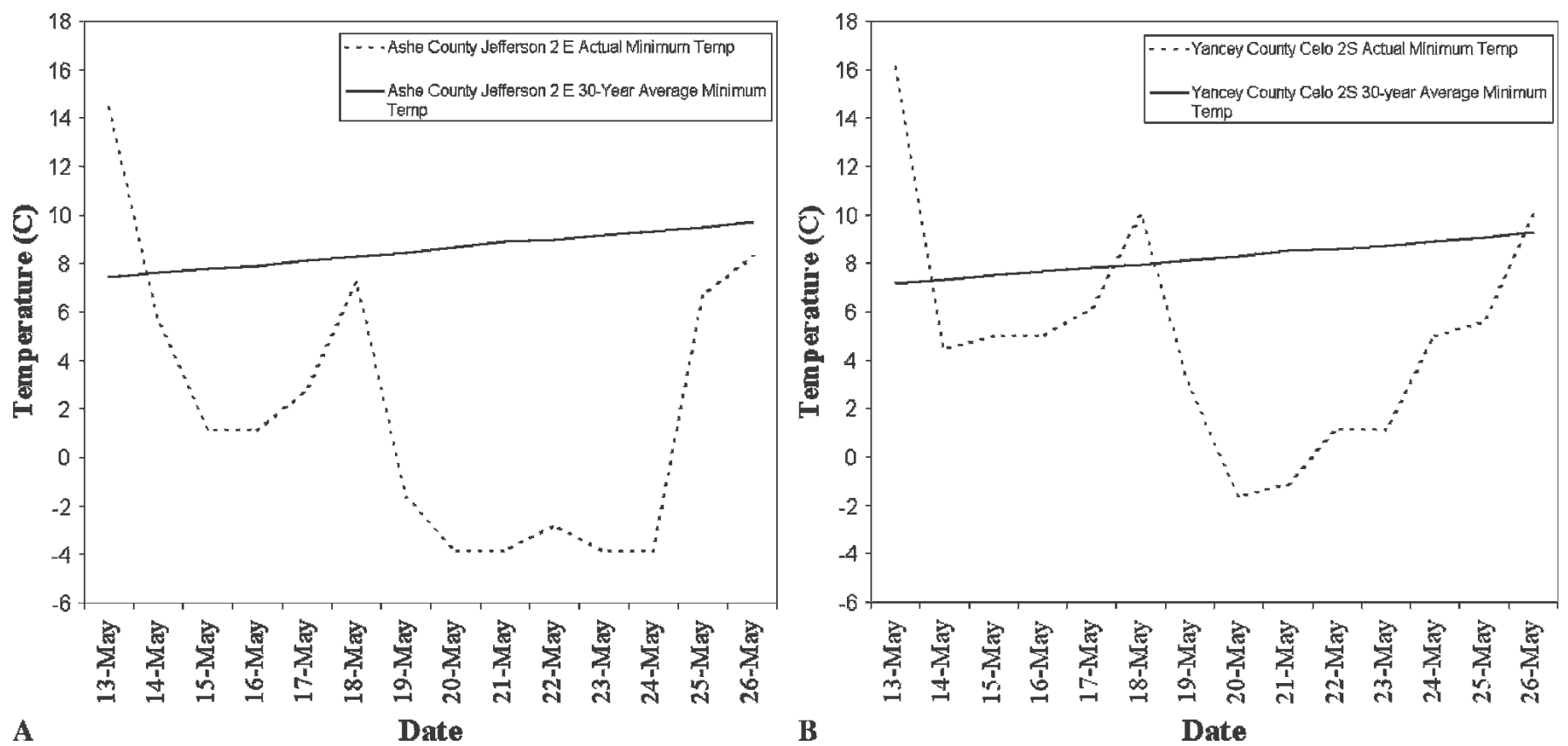

Fig. 2. The actual minimum temperature (dashed) and the 30-year average minimum temperature (solid) in degrees Celcius for the dates of 13 May through 25 May 2002 in (A) Ashe County, N.C., and (B) Yancey County, N.C.

being damaged. Two was a medium level of lateral branch damage with $\approx 15 \%$ to $85 \%$ damage, and three was for heavy damage with over $85 \%$ of the lateral branches affected.

Statistical analysis. The linear model for the analysis of nursery bud flush data incorporated the following effects: seed source, family (source), block, block $\times$ source interaction, and block $\times$ family (source) interaction. All effects were considered random except seed source. The linear model for the field analysis incorporated the following effects: group, seed source, group $\times$ source interaction, site (group), source $\times$ site (group) interaction, family [group (source)], family [group (source) $\times$ site (group) interaction, and replication [site (group)]. All effects were considered random except for group and seed source. The general linear model (GLM) procedure in SAS (SAS Institute, 2003) was used to perform an analysis of variance on individual tree values for both the nursery and field data.

Family mean correlations were calculated for the terminal and lateral frost damage, parent elevation, bud flush dates in the nursery for the terminal and lateral buds, and height in the nursery and each year in the field for all sites using the correlation (CORR) procedure in SAS (SAS Institute, 2003). This was performed both by source and with sources pooled.

The families were ranked for mean height after 4 years in the field with all individuals included. The families were also ranked with only those having some amount of terminal frost damage included in the family means and with only those having no terminal frost damage included. In addition, the mean height after 4 years in the field across the top 25 families was calculated. Family mean correlations were also calculated for year 4 height among the three categories-all individuals, frost-damaged individuals, and nondamaged individuals - using the correlation procedure (CORR) in SAS (SAS Institute, 2003).

Individual-tree within population heritabilities were calculated for frost damage measurements and bud flush dates. Equation 1 was used to calculate individual-tree narrow sense heritability for the nursery collected data (bud flush dates):

$$
\mathrm{h}_{\mathrm{i}(\mathrm{p})}^{2}=4 \sigma_{\mathrm{f}(\mathrm{s})}^{2} /\left(\sigma_{\mathrm{f}(\mathrm{s})}^{2}+\sigma_{\mathrm{f}(\mathrm{s}) * \mathrm{~b}}^{2}+\sigma_{\mathrm{e}}^{2}\right)
$$

where $\sigma_{\mathrm{f}(\mathrm{s})}^{2}$ is the variance resulting from family (source) differences, $\sigma_{\mathrm{f}(\mathrm{s}) * \mathrm{~b}}^{2}$ is the variance resulting from family(source) $x$ block interaction, and $\sigma_{\mathrm{e}}^{2}$ is the error variance (Zobel and Talbert, 1991). Equation 2 was used to calculate individual-tree narrow sense heritability for the field data (frost damage measurements):

$$
\begin{aligned}
\mathrm{h}_{\mathrm{i}(\mathrm{p})}^{2}= & 4 \sigma_{\mathrm{f}(\mathrm{g}(\mathrm{s}))}^{2} /\left(\sigma_{\mathrm{f}(\mathrm{g}(\mathrm{s}))}^{2}\right. \\
& \left.+\sigma_{\mathrm{f}(\mathrm{g}(\mathrm{s})) * \text { site }(\mathrm{g})}^{2}+\sigma_{\mathrm{e}}^{2}\right)
\end{aligned}
$$

where $\sigma_{\mathrm{f}(\mathrm{g}(\mathrm{s}))}^{2}$ is the variance resulting from

family [group (source)] differences, $\sigma_{\mathrm{f}(\mathrm{g}(\mathrm{s}))}^{2} * \operatorname{site}(\mathrm{g})$ is the variance resulting from family [group (source)] $\times$ site (group) interaction, and $\sigma_{\mathrm{e}}^{2}$ is the error variance (Zobel and Talbert, 1991). The variance components of random effects were estimated by the restricted maximum likelihood (REML) method in the variance component procedure (VARCOMP) in SAS (SAS Institute, 2003). A Tukey test among source least squares means was performed for the level of lateral frost damage by source with a 0.05 level of significance. This was calculated using the Tukey option in the general linear model (GLM) procedure in SAS (SAS Institute, 2003).

\section{Results}

The percentage of trees showing lateral frost damage at each site is given in Table 2 . Sources did not differ for terminal frost damage, but significant source differences did exist for lateral frost damage $(P \leq$ 0.0001 ) (Table 3 ). Tukey test results also showed significant source differences for lateral frost damage with the Grandfather

Table 3. Results from an analysis of variance for the terminal leader and lateral branch frost damage variables in a 3-year-old Fraser fir progeny test series.

\begin{tabular}{lccc}
\hline Source & DF & $\begin{array}{c}\text { Terminal frost } \\
\text { damage }\end{array}$ & $\begin{array}{c}\text { Lateral frost } \\
\text { damage }\end{array}$ \\
\hline Group & 1 & 2.70 & 0.76 \\
Source & 5 & 1.21 & $5.97 * * *$ \\
Group*source & 5 & 1.75 & 0.55 \\
Site (group) & 6 & $156.78^{* * *}$ & $78.43^{* * *}$ \\
Source*site (group) & 30 & 1.27 & $2.95^{* * *}$ \\
Family (source) & 177 & $1.78^{* * *}$ & $3.24 * * *$ \\
Family (group)*site (source) & $524 / 525$ & 1.47 & $1.85^{* * *}$ \\
Replication (site [group]) & 279 & $10.17^{* * *}$ & $44.50^{* * *}$ \\
\hline
\end{tabular}


Mountain source having significantly greater average lateral frost damage than the other five sources (Table 4). There were significant differences among families for both terminal and lateral frost damage $(P \leq 0.0001)$ as shown in Table 3. For lateral frost damage, significant source $\times$ site interactions and family $\times$ site interactions were also present $(P \leq 0.0001)$.

When all sources were pooled, significant positive family mean correlations existed for terminal and lateral frost damage with height for all years $(P \leq 0.05)$ (Table 5). As expected, parent elevation was negatively correlated with height in year $4(P \leq 0.05)$ (Table 5). Highly significant family mean associations also occurred between lighter lateral frost damage and later terminal and lateral bud flush dates in the nursery $(P \leq$ 0.0001 ) (Table 5). The correlations between bud flush dates and frost damage were negative and significant for lateral damage but

Table 4. Fraser fir lateral branch frost damage by source showing the percent of individuals in each damage class rating, the mean frost damage value, the Tukey grouping for the mean frost damage, the mean parent elevation, and the range in family means for lateral frost damage. ${ }^{\mathrm{z}}$

\begin{tabular}{|c|c|c|c|c|c|c|c|}
\hline & \multicolumn{4}{|c|}{ Percent in damage class } & \multirow{2}{*}{$\begin{array}{c}\text { Mean frost } \\
\text { damage }\end{array}$} & \multirow{2}{*}{$\begin{array}{c}\text { Parent } \\
\text { elevation }(\mathrm{m})\end{array}$} & \multirow{2}{*}{$\begin{array}{c}\text { Range in } \\
\text { family means }\end{array}$} \\
\hline & None & Light & Medium & Heavy & & & \\
\hline Grandfather Mountain & 34.98 & 38.44 & 19.77 & 6.81 & $0.98 \mathrm{a}$ & 1544 & $0.49-1.48$ \\
\hline Great Smoky & 39.39 & 36.45 & 19.25 & 4.92 & $0.89 b$ & 1802 & $0.53-1.46$ \\
\hline Roan Mountain & 37.65 & 39.59 & 18.82 & 3.94 & $0.89 \mathrm{~b}$ & 1709 & $0.52-1.40$ \\
\hline Black Mountains & 39.75 & 39.62 & 16.91 & 3.73 & $0.85 \mathrm{c}$ & 1723 & $0.42-1.50$ \\
\hline Mt. Rogers & 40.38 & 40.03 & 16.12 & 3.47 & $0.82 \mathrm{c}$ & 1597 & $0.40-1.31$ \\
\hline Balsam Mountains & 41.19 & 39.22 & 16.32 & 3.28 & $0.82 \mathrm{c}$ & 1722 & $0.42-1.26$ \\
\hline
\end{tabular}

${ }^{\mathrm{z}}$ Lateral branch frost damage was scored from 0 to 3 , with 0 being no damage and 3 being heavy damage. not for terminal damage. In addition, higher parent elevation was significantly associated with later lateral bud flush dates in the nursery $(P \leq 0.01)$ (Table 5$)$. It is not known whether bud flush dates in the nursery correlated with bud flush dates in the field.

When these correlations were studied within each source, the Great Smoky Mountain source was the only source that showed many significant associations among the various traits studied. Within the Great Smoky Mountain source, there were significant negative family mean correlations between parent elevation and height for all years $(P \leq 0.01)$ (Table 6). Later lateral and terminal bud flush dates in the nursery were also significantly associated with higher parent elevation $(P \leq 0.001)$ and with lower height in year $4(P \leq 0.05)$ (Table 6$)$. Later terminal bud flush dates in the nursery were significantly associated $(P \leq 0.05)$ with less terminal and lateral frost damage within the Great Smoky Mountain source in the field. Within the Great Smoky Mountain source,

Table 5. Family mean correlations among various traits averaged over eight Fraser fir progeny test sites $(\mathrm{N}=188)$.

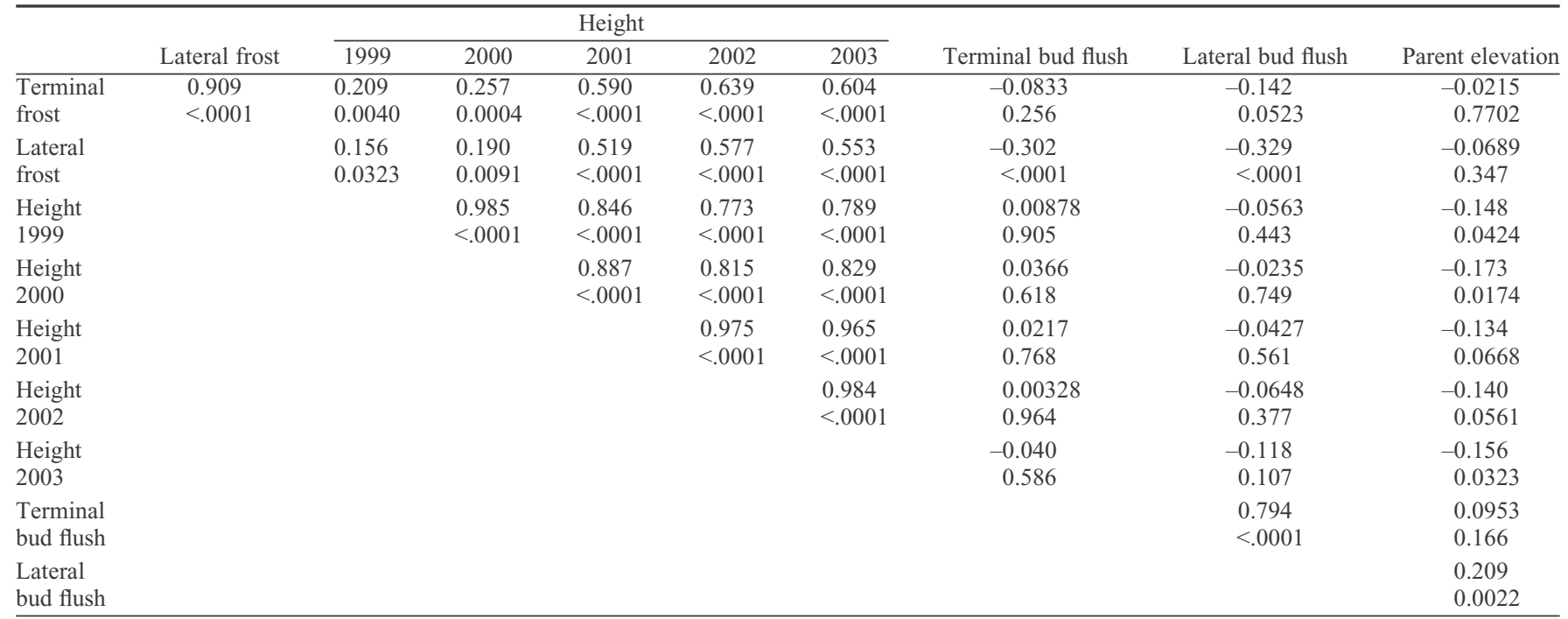

Table 6. Family mean correlations among various traits averaged over eight Fraser fir progeny test sites for the Great Smoky Mountains source only $(\mathrm{N}=46)$.

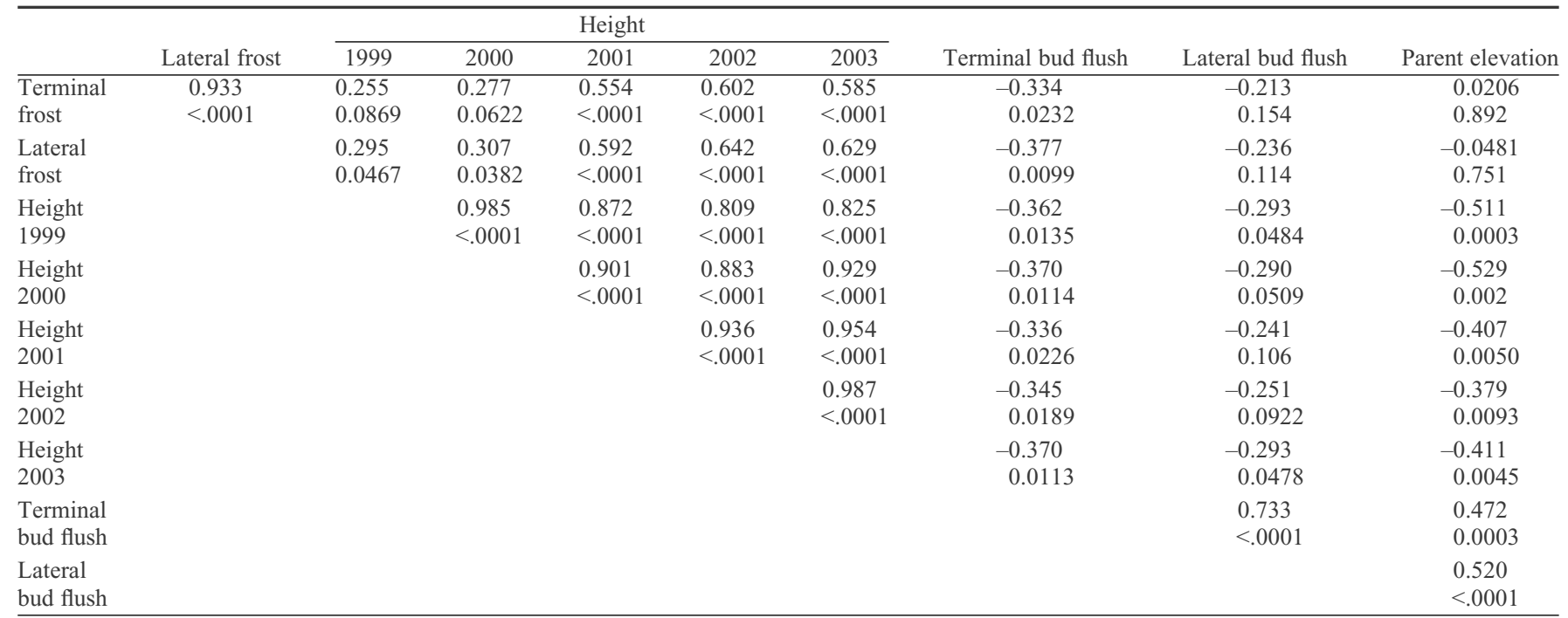


there were also significant positive correlations $(P \leq 0.0001)$ between terminal and lateral frost damage and height in years 2, 3, and 4 as was seen when all sources were included. The same trends were not consistent within the other five sources tested.

The dates of bud flush in the nursery were highly heritable with terminal bud flush date having a heritability of 0.85 and lateral bud flush date having a heritability of 0.73 with fairly low standard errors (Table 7). The heritability values for the measures of frost damage were much lower with a heritability of 0.045 for terminal frost damage and 0.14 for lateral frost damage (Table 8).

The family that ranked first for mean height after 4 years was still ranked first whether frost-damaged individuals were included in the analysis or not. The mean height for this same top-ranked family was calculated in three ways, including all individuals, including only those with some amount of frost damage, and including only individuals with no frost damage, and the means were 136,134 , and $139 \mathrm{~cm}$, respectively. When the top 25 families for year 4 height in each of these categories was compared, at least 19 of the 25 families were the same in all cases (Table 9). The family mean height of the 25 top-ranked families was $128 \mathrm{~cm}$ when all individuals were included, whereas it was $124 \mathrm{~cm}$ when only those individuals with terminal frost damage were included and was $132 \mathrm{~cm}$ when only those individuals with no terminal frost damage were included. With all sources pooled, family mean heights in the years before the late frost were highly significantly correlated $(P \leq 0.0001)$ to the height in years 3 and 4 , the year of the frost and the year after the frost (Table 5). In addition, family mean heights in year 4 for those individuals with no terminal frost damage were highly significantly associated $(P \leq 0.0001)$ with family mean heights for those individuals with terminal frost damage (Table 9).

\section{Discussion}

Amounts of frost damage varied greatly among test sites with the Ashe, Yancey, and Madison County sites having the highest percentage of damaged trees. This variation may have been the result of differences in the temperatures seen at each of these sites. Low, flat areas often act as frost pockets where cold air drains off sloped areas and accumulates. Ashe, Yancey, and Madison Counties were among the test sites with the lowest elevations and were located in low-lying depressions. In addition, trees at these lower elevation sites may have had an earlier bud flush that spring than those at other test sites, increasing the amount of frost damage.

Grandfather Mountain, having significantly greater average lateral frost damage than the other five sources, also had the lowest average parent elevation. The positive correlations between terminal and lateral frost damage and height for all years indicate that if families are selected based on faster growth, they may be more susceptible to frost

Table 7. Variance component estimates and individual within population heritability for date of bud flush in the nursery for Fraser fir seedlings.

\begin{tabular}{lcc}
\hline & Terminal bud flush & Lateral bud flush \\
\hline Variance (family [source]) & 2.424 & 2.702 \\
Variance (replication) & 0.0624 & 0.170 \\
Variance (source*replication) & 0 & 0 \\
Variance (family [source]*replication) & 0.170 & 1.117 \\
Variance (error) & 8.864 & 11.051 \\
Heritability & 0.85 & 0.73 \\
Standard error of heritability & 0.0712 & 0.0705 \\
\hline
\end{tabular}

Table 8. Variance component estimates and individual within population heritability for Fraser fir frost damage measurements during the third year in the field.

\begin{tabular}{lcc}
\hline & Terminal frost & Lateral frost \\
\hline Variance (site [group]) & 0.249 & 0.398 \\
Variance (source*site [group]) & 0.000177 & 0.00222 \\
Variance (family [group*source]) & 0.00369 & 0.00935 \\
Variance (site*family [group*source]) & 0.00488 & 0.00727 \\
Variance (replication [group*site]) & 0.0444 & 0.136 \\
Variance (error) & 0.317 & 0.244 \\
Heritability & 0.045 & 0.14 \\
Standard error of heritability & 0.0111 & 0.0216 \\
\hline
\end{tabular}

Table 9. Fraser fir family mean correlations (r) of year 4 height for all individuals with level of significance and the number of families in the top 25 for year 4 height in common $(\mathrm{N})$ between those with frost damage (terminal or lateral) and those without any frost damage.

\begin{tabular}{lcc}
\hline & \multicolumn{1}{c}{ Frost-damaged } & No frost damage \\
\hline All & $\mathrm{r}=0.937 P<0.0001 \mathrm{~N}=22$ & $\mathrm{r}=0.989 P<0.0001 \mathrm{~N}=22$ \\
Frost-damaged & $\mathrm{r}=0.898 P<0.0001 \mathrm{~N}=19$ \\
\hline
\end{tabular}

damage. Correlations between parent elevation and progeny height when sources were pooled as well as within the Great Smoky Mountain source indicated that individuals from lower elevations produced faster growing offspring. In a prior progeny test series with Fraser fir, it was also found that low elevation sources tended to have faster height growth than high elevation sources (Arnold and Jett, 1995; Jett et al., 1993; Li et al., 1988). These same trends have also been shown in grand fir [A. grandis (Dougl. ex D.Don) Lindl.] and Saghalien fir [A. sachalinensis (F. Schmidt) Mast.] (Eiga and Sakai, 1984; Xie and Ying, 1993). The significant correlations among lighter lateral frost damage and later terminal and lateral bud flush dates in the nursery agrees with other studies done with coastal Douglas fir, Norway spruce, as well as Abies species, which all showed strong correlations between greater spring frost damage and earlier bud flush date (Aitken and Adams, 1997; Hannerz et al., 1999b; Jones and Cregg, 2006). Results also indicate that progeny of parents from higher elevations tend to have later lateral bud flushing in the nursery. In addition, the significant negative correlation within the Great Smoky Mountain source between terminal and lateral bud flush dates in the nursery and height in year 4 indicates that individuals with greater height growth may also have earlier bud flush dates. This tradeoff between selecting for height and spring frost resistance resulting from earlier bud flush has been shown in a prior study with Douglas fir (Hannerz et al., 1999a).

The varied results for correlations within other sources may be the result of a smaller range in elevations sampled within them; the Great Smoky Mountain source was sampled from the greatest range of elevations, from 1487 to $1998 \mathrm{~m}$. The Great Smoky Mountain source also had the greatest number of families included in the test; 46 families from this source were included, whereas some of the other sources had as few as 24 families included.

The high heritabilities for bud flush dates seen here agree with results found in other species (Aitken and Adams, 1997; Hannerz et al., 1999b). The heritability values for frost damage were lower, but higher heritability values than seen here have been found for other species such as coastal Douglas fir (Aitken and Adams, 1997; O'Neill et al., 2000). As a result of the higher heritability values for bud flushing and the fact that later flushing individuals seem to be more resistant to a late spring frost, using bud flushing dates as a criterion in making selections for use in the Christmas tree industry may increase frost resistance. However, it is likely that many of the same families would be selected in terms of fast height growth whether the late spring frost had occurred or not as a result of the significant family mean correlations between height for those with frost damage and those without frost damage. Also, the same family is ranked first for height growth when only those with frost damage are included versus when only those without frost damage 
are included, and most of the same families occur in the top 25 for year 4 height for all categories. It appears that the frost damage does not greatly affect the rotation age height, because most of the fast-growing individuals can quickly make up for any loss of height from a late frost by developing a lateral branch into a leader if the frost damage occurs at least 1 year before harvest. It is not known whether rotation age quality was affected by the frost damage. Frost damage would be more of a problem the closer to the harvest date that it occurs, because it took at least 2 to 3 years for most evidence of this frost damage to disappear. Therefore, frost damage occurring in older trees could have more of an economic impact.

Future work should involve studying bud flush dates for Fraser fir in the field. In addition, the possible effect of climatic warming on the risk of spring frost damage is of interest. Sampling for more variation in elevation within seed sources should also be done to more thoroughly analyze the effects of parent elevation on height growth, date of bud flush, and spring frost susceptibility.

\section{Literature Cited}

Aitken, S.N. and W.T. Adams. 1997. Spring cold hardiness under strong genetic control in Oregon populations of Pseudotsuga menziesii var. menziesii. Can. J. For. Res. 27:1773-1780.

Anekonda, T.S., W.T. Adams, S.N. Aitken, D.B Neale, K.D. Jermstad, and N.C. Wheeler. 2000.
Genetics of cold hardiness in a cloned full-sib family of coastal Douglas-fir. Can. J. For. Res. 30:837-840.

Arnold, R.J. and J.B. Jett. 1995. Seed source variation for growth and quality traits of Fraser fir Christmas trees: Rotation age results. South. J. Appl. For. 19:157-161.

Beck, D.E.1990. Abies fraseri (Pursh) Poir. Silvics of North America. Vol 1. In: R.M. Burns and B.H. Honkala (eds.). Conifers, Handbook 654. Washington, D.C., U.S. Dept. of Agr., Forest Service.

Chapman, A.G. and R.D. Wray. 1989. Christmas trees for pleasure and profit. Rutgers Univ. Press, New Brunswick, N.J.

Dull, C.W., J.D. Ward, H.D. Brown, G.W. Ryan, W.H. Clerke, and R.J. Uhler. 1988. Evaluation of spruce and fir mortality in the Southern Appalachian Mountains. Atlanta, Ga., Forest Service, Southern Region: 92.

Eiga, S. and A. Sakai. 1984. Altitudinal variation in freezing resistance of Saghalien fir (Abies sachalinensis). Can. J. Bot. 62:156-160.

Emerson, J.L. 2004. Genetic variation in young Fraser fir progeny tests. North Carolina State Univ., Raleigh, MS Thesis.

Hannerz, M., S.N. Aitken, J.N. King, and S. Budge. 1999a. Effects of genetic selection for growth on frost hardiness in western hemlock. Can. J. For. Res. 29:509-516.

Hannerz, M., J. Sonesson, and I. Ekberg. 1999b. Genetic correlations between growth and growth rhythm observed in a short-term test and performance in long-term field trials of Norway spruce. Can. J. For. Res. 29:768-778.

Jett, J.B., S.E. McKeand, Y. Liu, and W.T. Huxster 1993. Seed source variation for height and crown traits of Fraser fir Christmas trees. South. J. Appl. For. 17:5-9.

Jones, G.E. and B.M. Cregg. 2006. Budbreak and winter injury in exotic firs. HortScience 41:143-148.

Li, B., J.B. Jett, and R.J. Weir. 1988. A preliminary study of geographic variation in Fraser fir seedlings. South. J. Appl. For. 12:128132.

Li, P. and W.T. Adams. 1993. Genetic control of bud phenology in pole-sized trees and seedlings of coastal Douglas-fir. Can. J. For. Res. 23:1043-1051.

McKeand, S., F. Bridgewater, C. McKinley, J.B. Jett, and R. Arnold. 1995. 1994 seed collection from natural stands of Fraser fir and plans for breeding and genetics research at NCSU Limbs and Needles 22:4,6-7.

Nichols, T.J. 1991. Shearing. In: J.E. Johnson (ed.). Christmas tree production manual. Virginia Cooperative Extension Publication 420 075:79-103.

O'Neill, G.A., S.N. Aitken, and W.T. Adams 2000. Genetic selection for cold hardiness in coastal Douglas-fir seedlings and saplings. Can. J. For. Res. 30:1799-1807.

SAS Institute, Inc. 2003. SAS/STAT user's guide, version 8. Cary, N.C.

Xie, C.Y. and C.C. Ying. 1993. Geographic variation of grand fir (Abies grandis) in the Pacific coast region: 10-year results from a provenance trial. Can. J. For. Res. 23:10651072.

Zobel, B. and J. Talbert. 1991. Applied forest tree improvement. Waveland Press, Inc., Prospect Heights, Ill. 